\title{
Cultuur en ziekte
}

Citation for published version (APA):

Appels, A. (1983). Cultuur en ziekte. Maastricht University. https://doi.org/10.26481/spe.19830511aa

Document status and date:

Published: 05/11/1983

DOI:

10.26481/spe.19830511aa

Document Version:

Publisher's PDF, also known as Version of record

\section{Please check the document version of this publication:}

- A submitted manuscript is the version of the article upon submission and before peer-review. There can be important differences between the submitted version and the official published version of record.

People interested in the research are advised to contact the author for the final version of the publication, or visit the DOI to the publisher's website.

- The final author version and the galley proof are versions of the publication after peer review.

- The final published version features the final layout of the paper including the volume, issue and page numbers.

Link to publication

\footnotetext{
General rights rights.

- You may freely distribute the URL identifying the publication in the public portal. please follow below link for the End User Agreement:

www.umlib.nl/taverne-license

Take down policy

If you believe that this document breaches copyright please contact us at:

repository@maastrichtuniversity.nl

providing details and we will investigate your claim.
}

Copyright and moral rights for the publications made accessible in the public portal are retained by the authors and/or other copyright owners and it is a condition of accessing publications that users recognise and abide by the legal requirements associated with these

- Users may download and print one copy of any publication from the public portal for the purpose of private study or research.

- You may not further distribute the material or use it for any profit-making activity or commercial gain

If the publication is distributed under the terms of Article $25 \mathrm{fa}$ of the Dutch Copyright Act, indicated by the "Taverne" license above, 


\title{
Cultuur en ziekte
}

\author{
Dr. A. Appels
}

Rede uitgesproken bij de aanvaarding van het ambi van gewoon hoogleraar in de medische psychologie aan de Rijksuniversiteit Limburg op 5 november 1982.

Mijnheer de rector,

geachte collega's,

beste vrienden en familieleden.

„Indien een vis ontdekkingen zou kunnen doen, zo heeft men wel gezegd, dan zou zijn laatste ontdekking zijn het bestaan van het water. Pas op de kar van de visboer zou hij weten wat het betekent een waterdier te zijn. Zo moet men zich ook niet verwonderen, dat de mens eerst in het allerjongste verleden heeft ontdekt, hoezeer hij gevormd is door de hem omringende cultuur".

Met deze zinnen begon mijn leermeester H. Fortmann in 1959 zijn inaugurale rede over de aard en doelstellingen van de cultuurpsychologie. "Wat is er met de mens gebeurd?" was de titeI van zijn voordracht (Fortmann, 1961). En de vraag: wat is er in deze eeuw met de mens gebeurd, dat hij steeds meer aan zijn hart moet doodgaan, zou de ondertitel van deze inaugurale kunnen $z i j n$, ware het niet dat ik in deze openbare les wil uitleggen waarom ik geloof dat de hedendaagse epidemie van hart- en vaatziekten langzaam uitdooft om waarschijnlijk opgevolgd te worden door een golf van anorexia nervosa.

\section{Ziektes weerspiegelen een levensstijl}

Wanneer ik ieder van $U$ de vraag zou voorleggen wat voor soort mensen veel kans hebben op het krijgen van een hartinfarct en waarom er tegenwoordig zoveel van dat soort zijn, dan zullen velen spanningen en een druk leven noemen en voor een verklaring verwijzen naar het jachtige, haastige leven in de twintigste eeuw.

Dit antwoord is juist maar nog grof en onvolledig. Het is de taak van de gedragswetenschappen en van de medische psychologie in het bijzonder om dit beeld te precizeren en door onderzoek aan te tonen dat gedragsfactoren naast bijvoorbeeld hoge bloeddruk en cholesterol de kans op een infarct verhogen. Deze noodzakelijke verfijning is onder meer tot stand gebracht in de beschrijving van het karakter van de infarctpatiënt en met name in de studies over het type A gedragspatroon. Dit gedragspatroon wordt gekenmerkt door jachtigheid, haast, ambitie, agressiviteit, een grote betrokkenheid op het werk en het continu gevoel tegen de klok in te moeten werken. Wij weten nu met vrij grote zekerheid, dat A-types tweemaal zoveel kans hebben op het krijgen van 
een infarct dan de rustiger levende B-types bij wie dit gedragspatroon niet of nauwelijks ontwikkeld is (Rosenman e.a., 1975; Rosenman en Chesney, 1980). Maar waarom zijn er dan zoveel A-types, zijn zoveel mensen bezig met een continu gevecht greep op hun levensomstandigheden te houden? Waarom is deze angina temporis de belangrijkste doodsoorzaak geworden?

Ziektes, die aan bepaalde gedragsvormen gebonden zijn weerspiegelen een levensstijl. Deze levensstijl weerspiegelt op haar beurt een cultuur. Dezelfde cultuur geeft vorm aan een veelheid van instituties en uitingsvormen, waaronder de kunst. Een ziekte die kenmerkend is voor een tijd moet dus iets gemeenschappelijks hebben met de kunst van die tijd. Het thema van deze openbare les is daarom: wat kan een analyse van de moderne kunst ons leren over de voedingsbodem van die gedragsvormen, die het ontstaan van sommige ziekten bevorderen?

Wanneer wij het hartinfarct als cultuurziekte benaderen vanuit de kunst, vergelijken wij twee zeer verschillende uitdrukkingswijzen, twee afzonderlijke talen. De overeenkomst tussen beide moet daarom niet gezocht worden in de inhoud, in wat artiesten schilderen en A-types doen, maar in formele kenmerken, in de wijze waarop kunstenaars schilderen of componeren en hoe A-types hun leven organiseren.

De wijze waarop mensen kijken naar en omgaan met de dingen verandert wanneer de wereld waarin zij leven verandert. Wezenlijke veranderingen, en ik geloof dat dat vrijwel altijd veranderingen in de economische inrichting van de maatschappij zijn, dwingen mensen op een nieuwe manier naar de wereld te kijken. De waarneming zelf verandert in de loop van de tijden, en met name twee centrale, formele kenmerken van de waarneming, namelijk de wijze waarop met ruimte en tijd wordt omgegaan en de positie die de waarnemer ten opzichte van zijn omgeving inneemt ${ }^{1}$. Passen we dit toe op de kunst dan moeten we letten op de aan- of afwezigheid van het centraal perspectief in schilderkunst en op de rol die beweging in het kunstwerk speelt. Passen we dit toe op gedrag dan moeten we letten op de wijze waarop de wereld aan iemand verschijnt, als cen stabiele, apriori vastgelegde ruimte, als gegeven verhoudingen of als een open proces, waarin alles veranderbaar is, en ten tweede op de betekenis van de factor tijd voor de organisatie van het gedrag.

Ik wil $U$ iets van deze verwantschap tussen twee ogenschijnlijk heel verschillende uitdrukkingswijzen van een cultuur illustreren aan de hand van een wandeling door de kunstgeschiedenis. Op het einde hiervan zullen we weer bij ons onderwerp hart- en vaatziekten en anorexia nervosa uitkomen in de hoop dat deze excursie het gedrag dat an het ontstaan van deze ziekten mede ten grondslag ligt, transparanter heeft gemaakt.

\section{Een wandeling door de kunstgeschiedenis}

Beïnvloed door de filosotie van Plato heeft de oud christelijke kunst de nadruk gelegd op de afstandelijkheid en onbeweeglijkheid van God en de eeuwige wetten, die deze wereld beheersen. Het gouden fond en de frontale positie van de figuren op de byzantijnse mozaïken drukken een eeuwige tijdloosheid uit. 
Tol diep in de feodale middeleeuwen met haar vastgelegde sociale hiërarchie blijven ruimte en tijd onbelangrijke organisatieprincipes in de schilderkunst. In middeleeuwse schilderijen is het perspectief vaak afwezig en kan een figuur, bijwoorbeeld Christus, twee of meer keer in hetzelfde landschap aanwezig zijn. Het centraal perspectief is niet afwezig ondat de artiest het niet zou kennen, maar omdat ruimte en tijd en daarmee de exacte plaatsbepaling van gebeurtenissen voor hem geen belangrijke waarnemingscategorieën waren. Tijd was een categorie van het goddelijke. En daarom bestond er een verbod om rente over een uitgeleend kapitaal te berekenen. Men zou dan immers iets, namelijk tijd, verhandelen dat uitsluitend aan God toebehoort. Renteberekening was daarom woeker en het woekeren met tijd een goddeloze zaak.

De feodale wereld eindigt in de renaissance. Deze begint in Italië omdat dit het eerste land in Europa was, dat een sterke economische opbloei doormaakte. Het had de kruistochten georganiseerd en gefinancierd. Vrije economische competitie, het bankwezen en de boekhoudkunde begonnen in Italiè. In deze nieuwe economische orde werden tijd en ruimte belangrijke categoricën. De nieuwe boekhouding, het bankwezen en de berekening van rente eisen cen precieze localisatie van gebeurtenissen en dus een rationele organisatie van de tijd. Deze rationele organisatie van de waarneming komt in de kunst tot uiting in de „uitvinding" van het centraall perspectief. De ruimte werd continu en omsloot de gebeurtenissen. De toeschouwer integreert en coördineert wat hij ziet vanuit één enkelvoudige principe. Hij heeft een duidelijke positie ten opzichte van zijn omgeving. Hij staat tegenover een wereld, die open ligt voor zijn ingrepen. Het eerste schilderij waarin het centraal perspectief bewust werd toegepast is het fresco „De Triniteit” dat Massacio in 1427 in de Santa Maria Novella te Florence schilderde. Dit werk was destijes dermate revolutionair dat de mensen de kerk uitliepen om te kijken of er soms geen gat in de muur gemaakt was. Waarschijnlijk is Massacio zich niet bewust geweest van de redenen waarom het centraal perspectief in zijn dagen zo'n belangrijke waarnemingscategorie was geworden. Mensen zijn als vissen die op stroomveranderingen van het water reageren en deze reactie kan vaak vooruit lopen op het volle bewustzijn van de veranderingen.

Het centraal perspectief wordt in de barok op een speciale wijze ingevuld. De absolute monarch komt in het verdwijnpunt te staan, de ordening van do wereld richt zich op hem, zoals bijwoorbeeld de tuinen van Versailles en van het Weense hof illustreren. Aan de barok en haar elegante rococodochter lijkt geen einde te komen totdat de nieuwe nuchterheid van de verlichting de drukke krulinterieurs vervangt en het claccisisme de decors voor de revolutie levert. De nouveau riche, die in de $19 \mathrm{e}$ eeuw de plaats van de weggezonden adel gaat innemen is nog stijlloos en doorloopt nog eens alle stijlen varn neoclaccisme tot neobarok op zoek naar een eigen vormgeving.

De $19 \mathrm{e}$ eeuw is de periode van de neo-stijlen en de periode waarin zich door de uitvinding van de stoommachine en andere technologische innovaties de oude manifactuur zich ontwikkelde tot de moderne industrie. Het principe van de relatieve meerwaarde, dat wil zeggen het opvoeren van winst door toename van de produktiviteit in dezelfde arbeidstijd, ging de economie en het leven van miljoenen beheersen. Geld werd tijd. „De porieën van de tijd wer- 
den gevuld" zal Marx (1975) daarover schrijven. In een wereld die langzamerhand dynamischer werd, was de ervaring dat alles snel veranderde een nieuwe sensatie. Velen ontwluchtten die wereld en gaan op voyage interieur, op zoek naar verloren gewaande betekenissen, mysteries, intrapsychische vergezichten, onbekende en onbewuste lagen in de mens. De wereld van het symbolisme is de geboortegrond van al die vormen van psychologie, die de diepste werkelijkheden zoekt in onbewuste of verdrongen driften, emoties of archetypen, waartoe men met duiding van dromen of antwoorden op inktvlekkentesten toegang zou krijgen. Er is een intieme verwantschap tussen het werk van de symbolische schilder Gustav Klimt en dat van de psycho-analyticus Sigmund Freud (Schorske, 1980).

De ervaring dat de wereld dynamischer en veranderlijker werd vond een eerste uitdrukking in die kunst, die aangeeft dat een straat of een station van moment tot moment een ander aanzien hebben: het impressionisme, de kunst van de wuchtigheid en de veranderlijkheid (Hauser, 1975). In deze wereld begint de observator zijn vaste, veilige positje te verliezen. Bij Cezanne ziet men voor het eerst de twijfel opkomen over de positie van waaruit de werkelijkheid benaderd moet worden. De ruimte begon discontinu te worden.

Het gevoel dat tijcl de centrale categorie in het leven werd is het sterkst verwoord door het futurisme, een stroming, die in de tijd grotendeels samenvalt met het kubisme en daar ook inhoudelijk mee verwant is. Wij zitten dan in de periode voor de eerste wereldoorlog. Op deze periode ga ik hier wat dieper in omdat de veranderingen die zich dan in kunst en wetenschap voltrekken in mijn ogen het duidelijkst laten zien hoe de tweede industriële revolutie de waarneming van ruinte en tijd wezenlijk heeft veranderd. Veel van wat later moderne kunst zal heten begint in deze jaren. En aăn de bron is het water het helderst. De essentie van deze verandering is dat tot dan toe merisen in de ruimte en in de tijd geleefd hadden. Nu echter komt de tijd en de ruimte in de mensen, in hun denken en voelen en in hun waarneming. Dat is de voedingsbodem voor het ontstaan van het jachtige, haastige A-type en daarmee voor het ontstaan van hart- en vaatziekten als epidemisch probleem. Ook in vroegere eeuwen kwamen atherosclerotische ziekten voor, maar vanaf het begin van deze eeuw verandert het leven zo dat hart- en vaatziekten konden gaan uitgroeien tot de eerste doodsoorzaak.

\section{De dymanisering van bet wereldbeeld}

De jaren 1900-1914 waren wol aandacht voor beweging en tijd (Pieterson, 1981). Taylor ontwikkelt dan zijn scientific management, waarin onder meer de studie van de minimale tijd die een arbeidshandeling mag duren een centrale plaats inneemt en de stopwatch bujgevolg het belangrijkste wetenschappelijk instrument was. In deze jaren publiceerde Frank Gilbreth, een van de eerste ergonomische studies, waarin hij liet zien hoe door tijd- en bewegingsstudies bij metselaars hun productiviteit verdrievoudigd kon worden. Dezelfde Gilbreth bezocht ook de operatiekamers in ziekenhuizen en rationaliseerde de operatietechniek door invoering van de zuster-schaar-methode: de chirurg zoekt niet meer naar de instrumenten maar deze worden hem aangereikt. Deze 
wereld van pragmatisme en rationele analyse van gedrag is ook de geboortegrond van de behavioristische psychologie, waarvan Watson in 1913 de grondslag legde. Het behaviorisme was daarmee vanaf den beginne doortrokken van de vooruitgangsverwachting van het begin van deze eeuw. Van de "prediction and control of human behavior" verwachtte men, dat zij de wereld zou kunnen omvormen tot een democratisch-behavioristisch utopia.

De futuristen vormen een groep kunstenaars, die dronken zijn van deze toekomstverwachting en de dynamisering van het wereldbeeld. Historisch gesproken startte het met een manifest dat de dichter Marinetti in 1909 publiceerde (Apolonio, 1973). Ik ga U daaruit wat voorlezen. Neemt $U$ daarbij weer in gedachten wat ik $U$ vertelde over de kenmerken van het A-type: jachtigheid, haast, ambitie, agressiviteit en het gevoel eeuwig tijd tekort te komen voor al datgene wat men zou willen doen. Ik citeer:

1. "Wij willen de liefde voor het gevaar bezingen, het energieke en vreesloze bestaan.

2. Tot nu toe heeft de literatuur een sombere onbeweeglijkheid, extase en slaap bejubeld. Wij willen de lof zingen van de agressieve daad, van de koortsachtige slapeloosheid, het gevecht van de racer, de dodelijke sprong, de stoot en de slag.

3. Wij verklaren dat de heerlijkheid van de wereld verrijkt is met een nieuwe schoonheid: de schoonheid van de snelheid. Een racewagen waarvan de motorkap is versierd met grote pijpen, als slangen met een explosieve adem, een loeiende auto, die op kartetsen lijkt te rijden, is mooier dan de Nikè van Samothrace.

4. Buiten strijd is er geen schoonheid meer. Een werk dat niet agressief is kan geen meesterwerk zijn.

5. Wij staan op het laatste voorgebergte der eeuwen! ..... Waarom zouden we omkijken als wat wij willen breken de mysterieuze deuren van het onmogelijke zijn. Tijd en ruimte stierven gisteren. Wij leven reeds in het absolute, omdat wij de eeuwige, alomtegenwoordige snelheid geschapen hebben.

6. Wij willen zingen van de grote massa's opgewonden door werk, door plezier en opstanden. Wij willen zingen van de veelkleurige, polyphone getijden van revolutie in moderne hoofdsteden. Wij willen zingen van de trillende nachtelijke gloed van arsenalen en scheepswerven, die vlammen net schrille electrische manen; gulzige treinstations, die met rook bestoken slangen verslinden; fabrieken, die aan de wolken opgehangen zijn met de kronkelende lijnen van hun rook; bruggen, die als reuze gymnasten over rivieren stappen, flitsend in de zon met een glans van messen; avontuurlijke sloomboten, die hun neus in de horizon steken; locomotieven met een brede borst, waarvan de wielen op de sporen staan als de hoeven van enorme stalen paarden, gebreideld door hun pijpen; en de zacht glanzende vlucht van vliegtuigen, waarvan de propellors klapperen in de lucht en enthousiast zijn als een juichende menigte".

Dat is niet de taal van de club van Rome. Integendeel. De futuristen zijn bezeten van de dynamiek, die het leven gat aannemen. De stad wordt bezongen om zijn lawaai, zijn drukte en kakofonie van geluiden. Dat is het intense leven. De plaats van de mens, van de observator is midden in dat ge- 
beuren. On deze innerlijke dynamiek te kunnen uitbeelden geven zij ruinten weer die elkaar interpenetreren en splitsen zij de beweging op in haar elementen, zoals Gilbreth dat toen deed bij metselaars en chirurgen. Men ziet dat bijvoorbeeld in Balla's weergave van een hondje (het beestje krijgt zeven staartjes om de kwispelbeweging weer te geven) of zijn ,meisje dat over een balkon rent". Deze Balla was zo gegrepen door wat de techniek aan nieuws te bieden had, dat hij zijn dochters Elica en Luce, propellor en electrisch licht, noemde (Tisdall en Bozzola, 1977).

Grote kunst is het in mijn smaak allemaal niet en ik vind het amusanter om hun opgewonden manifesten te lezen dan hun beelden en schilderijen te zien. De idee van de beweging werd in deze jaren rustiger en lucieder uitgebeeld door franse kunstenaars als Marcel Duchamp.

Het zijn de kubisten, met wie de futuristen zich overigens graag vergeleken, die het artistieke idioom vonden dal de veranderingen in de waarneming van ruimte en tijd en dus van de nieuwe positie van de observator in de autonome taal van de schilderkunst kon uitdrukken. Om dit toe te lichten lees ik U een gedeelte voor uit een lezing, die de schilder F. Léger in 1914 hield. De meeste zinnen zijn letterlijk weergegeven, sommige heb ik wat samengevat. „Wanneer de pictorale expressie veranderd is, dan komt dat omdat het moderne leven dit noodzakelijk gemaakt heeft. Het leven van moderne kunstenaars is veel gecondenseerder en complexer dan dat van mensen in vroeger eeuwen. Het ding dat uitgebeeld wordt staat niet meer stil. Wanneer men een landschap in een auto of sneltrein doorkruist verliest het landschap in descriptieve waarde, maar wint het in synthetische waarde. Het raam van de trein of de voorruit wan de auto hebben tesamen met hun snelheid de gebruikelijke manier waarop de dingen eruit zien veranderd. Een moderne man registreert meer dan honderd keer zoveel zintuigelijke indrukken dan de kunstenaar uit de achttiende eeuw. De condensatie van het moderne schilderij, haar verscheidenheid en het doorbreken van vormen komen er alle uit voort. Het leidt geen twijfel dat de evolutie van de manieren om ons te verplaatsen, en hun snelheid, iets te maken hebben met deze nieuwe manier van zien. De breuken met het verleden die in onze visuele wereld zijn opgetreden zijn ontelbaar. Ik kies het meest treffende. Het reclamebord dat een landschap brutaal doorsnijdt gehoorzamend aan de dictaten van de moderne commercie, is een van de dingen die de mensen van de zogenaamde goede smaak het kwaadst hebben gemaakt. En toch is dat gele of rode aanplakbord, dat in een teer landschap staat te schreeuwen, een van de beste verklaringen van het nieuwe schilderen: het zet de hele sentimentele en literaire conceptie van kunst ondersteboven en kondigt de komst van ware plastische contrasten aan. Vroeger had een landschap waarde in zichzelf; een witte, stille weg kon het doorkruisen zonder het te veranderen. Nu hebben de trein en de auto alle dynamische kwaliteiten voor zich opgeëist en wordt het landschap secondair, een afgeleide. De impressionisten hebben deze contrasten al gezien. Malar zij vertelden nog een verhaltje. Het moderne schilderij is helemaal gericht op deze contrasten. Zijn realisme is niet meer het realisme van de afbeelding maar dat van de conceptie. Een moderne schilder beschouwt het perspectief en de gevoelswaarde als negatieve middelen. De impressionisten hebben de dynamische beweeglijkheid uitgedrukt door contrasten van kleurtonen, maar wat de moderne schilder gebruikt is het multiple contrast 
van kleuren, lijnen en vormen" (Fry, 1966).

$U$ hoort, het zouden bijna de woorden van een futurist kunnen zijn. Maar Léger heeft geen interesse in snelheid om haarzelfswille maar on het generalizerende, synthetiserende effect die snelheid en beweging hebben op het oog van de observator. De kritiek van de kubisten op de futuristen was, dat de laatsten de dynamiek van de moderne wereld wilden uitbeelden door beweging weer te geven. Dat kan niet, zeggen de kubisten. De kwispelende staart van Balla's hondje is geschilderd vanuit een vast punt in de ruimte, dat als referentiepunt voor alle bewegingen dient. En zo'n punt bestaat niet. Dat is een illusie van de Renaissance. In het centraal perspectief kwamen alle lijnen bij de toeschouwer uit. Door de bewegende, dynamische positie van de observator is ieder observatiepunt iets toevalligs geworden, een teken van een toevallig moment waarop een bepaalde man op een bepaalde plats is.

Voor de kubisten is perspectief gezichtsbedrog. In een kubistisch schilderij worden daarom verschillende gezichtspunten tot een geheel gecombineerd. Want alleen de gelijktijdige verwerking van verschillende gezichtspunten laat zien hoe de dingen in hun conceptie ,an und für sich" zijn"2. Deze gelijktijdigheid van verschillende benaderingen van een voorwerp impliceert beweging en dus tijd. En zo wordt tijd als een apriori categorie in de afbeelding gebracht. Een schilderij is niet langer een dood stukje ruimte of een stukje gestolde tijd. Tijd en ruimte worden in de weergave van de werkelijkheid gebracht. Het realisme van de kubisten is niet dat van het mooie zicht op de dingen maar van het artistieke inzicht, in de opbouw in ruimte en tijd. Een beeld van Lipschitz bijvoorbeeld, laat zien hoe een musicerende man tesamen met zijn instrument is opgebouwd als een dynamische structuur, als de wiize waarop kristallen groeien (Berger, 1972).

Vanaf de tijd der kubisten zijn ruimte en tijd niet meer het reservoir waarin de dingen zich afspelen maar zijn zij gebeurtenissen op zichzelf geworden. De observator heeft zijn stabiele positie voor eeuwig verloren. De tijd, die in de Middeleeuwen nog iets was dat aan God toebehoorde en in de Renaissance iets wat de gebeurtenissen omsloot is op het einde van de tweede industriële revolutie iets geworden dat in de dingen, in mensen is.

De coördinaten van de warneming blijken in de eerste iwee decennia van deze eeuw grondig veranderd te zijn. Een dergellike verschuiving treedt ook op in de muziek. Vanaf de Renaissance was de westerse muziek gebaseerd op een hiërarchische toonorde, het diatonisch systeem met als centrale elementen de drieklank en de vastgelegde sleutel. De muzikale beweging ontstond doordat in de melodie de crieklank en de grondtoon verlaten werden, welke dynamiek uiteindelijk opgelost werd door een terugkeer naar de oorspronkelijke grondtoon. In wat wij de klassieke muziek noemen heeft de sleutel waarin een muziekstuk staat (bijwoorbeeld c-groot) dezelfde functie als het centraal perspectief in de schilderkunst. Deze ordeningsprincipes behoren tot hetzelfde socio-culturele systeem waarin de geometrische tuinen met hun gecentraliseerde focus ontworpen waren. Niet voor niets was Rameau, de hofcomponist van Lodewijk XV, de helderste en meest compromisloze theoreticus van de harmonieleer. Aan zijn strakke systeem had in de loop der tijden al menig componist getrokken, maar het is Schoenberg die in de jaren voor de eerste wereldoorlog het tonale systeem met zijn rationele, hiërarchische ordeningen 
doorbreekt om zoals hij betekenisvol zegt ,de dissonant te emanciperen", een tormulering die ogenblikkelijk herinnert aan Légers nadruk op bet contrast. Dit oplossen van de tonaliteit als het structurerend centrum van de muziek, het wegvallen van een vaste sleutel creêert een open universum, waarin alles met alles kan gaan clusteren. De componist, zegt Schoenberg, komt in een eindeloze ruimte en daarin structuur aan te brengen is niet minder dan die van God op de scheppingsdag (Schorske, 1980).

In de jaren 1900-1914 verliezen de traditionele, veilige coördinaten van ruinte en tijd hun betrouwbaarheid. Schilders vertrouwen het mathematisch perspectief niet meer, componisten verlaten de grondtoon als organiserend principe in de muziek en in 1905 publiceert Einstein de speciale relativiteitsleer, waarin hij in de taal van de physicus laat zien dat de oude coördinaten van tijd en ruimte ook onwar waren, dat "time and timing" onderling verwisselbaar zijn en dat wat de observator ziet van zijn toevallige positie afhangt.

In de eerste decennia van deze eeuw kwam de ruimte in beweging. De industrialisatie, het definitieve wegvallen van een socio-economische structuur, die op traditie gebouwd is, en het nieuwe artistieke en wetenschappelijk bewustzijn schiep eindeloos nieuwe mogelijkheden voor intellectuele, artistieke en econonische vernieuwingen. De ruinte kwam in beweging. In de kunst van de latere decennia ziet men dit in allerlei varianten terugkomen ${ }^{*}$. Ik wijs U slechts op de mobile's van Calder, die zo aardig zijn omdat ze speels laten zien hoe rumtelijke structuren door het kleinste briesje veranderd worden en op de beelden van Moore en Gabo, die niet meer in de ruimte staan als een stoer ruiterstandbeeld, maar die de ruimte er doorheen laten stromen als een middel waarmee het beeld gemaakt is.

In de jaren 1900-1914 wordt zichtbaar tot welke vormveranderingen in het menselijk denken, voelen en waarnemen de tweede industriele revolutie geleid heeft. Vanaf het moment dat schilders, componisten en physici in hun taal formuleren dat de tijd in de dingen is wordt het leven van miljoenen jachtiger en onzekerder, bij sommigen zelfs zozeer dat zij door psychologen A-type genoemd zullen gaan worden ${ }^{4}$. Toen de stroomsnellheid van het water veranderde ontstond bij de vissen een nieuw gedrag.

Onze tocht door de kunstgeschiedenis is inmiddels tamelijk lang geworden en verschillenden van $U$ zullen zich inmiddels al afgevraagd hebben wat men voor deze sierlijke bespiegelingen kan kopen, wat dit alles met de medische psychologie te maken heeft en waar de somatische en genetische factoren blijven. Welnu, de keuze van cultuur als invalshoek ontkent het belang van somatische en genetische factoren niet. Ook een psycholoog die kinderen heeft weet dat sommige karaktertrekken overgeërfd worden; de goede van de eigen familie, de slechte van de schoonfamilie. Ook de psycholoog weet dat hartinfarcten er altijd geweest zijn en altijd zullen blijven.

Hoe nuttig een reflectie op de cultuur is moet worden afgemeten aan de afleidingen die men daaruit maken kan. Psychologie is geen kunstgeschiedenis. Psychologie is tot aan het einde toe doordachte sociologie, de aan het individu uilgewerkte analyse van de wijze waarop socio-culturele configuraties het denken, waarnemen en handelen van het individu vormen, Een culturbeschouwing, zoals in deze voordacht gegeven wordt, behoort tot de grondstoflen waaruit de psychologie haar ideeën destilleert. Het psychologisch handwerk 
begint wanneer deze ideeën worden omgezet in toetsbare hypothesen. Het aardige van de medische psychologie is juist gelegen in de combinatie van theoretische bespiegeling en concrete, toetsbare afleidingen. Het woord afleiding gebruik ik overigens niet in de zin wan een logische deductie, maar als de uitwerking of toepassing van de socioculturele bespiegelingen op een concreet gebied. Wie niet durft te speculeren zal weinig nieuwe ideeën ontwikkelen. Wanneer empirisch onderzoek de juistheid van de hypothesen bevestigt bewijst dat niet dat ook de cultuur-psychologische beschouwing juist was. Er vinden immers niveau verwisselingen plaats. Men kan ook langs de verkeerde weg op een juiste hypothese komen. Het woord afleiding betekent hier een zoekrichting, een vooroordeel zo U wilt, een geloofsovertuiging van waaruit het empirisch werk wordt opgezet. Drie afleidingen wil ik noemen.

\section{Demografische ontwikkelingen}

De eerste afleiding betreft de demografische ontwikkeling van het hartinfarct als epidemie. Ingrijpende culturele veranderingen beginnen in de leidende maatschappelijke lagen en meestal zijn dat de hoogst opgeleidenen, om later overgenomen te worden door de lagere sociale klassen. Industriële en socio economische ontwikkelingen zijn in de geschiedenis door de hogere sociale lagen ontwikkeld. Niet voor niets bevat het communistisch manifest ook een hymne op de bourgeoisie. Industriële en socio-culturele ontwikkelingen komen voort uit een bepaalde leefwijze en roepen op hun beurt gedragscodes op, die mensen in staat stellen zich aan te passen en te anticiperen op nieuwe ontwikkelingen. Mede door het verschil in toegang tot alle informatie ontwikkelt een nieuwe gedragsstijl zich het eerst in de hogere sociale lagen. Een ziekte, die met een bepaalde leefwijze samenhangt zal dus het eerst optreden in de hogere sociale strata om na een aantal decennia de groepen met de laagste opleiding te bereiken. Marmot e.a. (1978) hebben laten zien dat de sterfte aan hart- en vaatziekten in Engeland in de dertiger jaren vooral voorkwam bij de hogere sociale strata (vandaar de naam managers ziekte) en nu geconcentreerd is bij de lagere opleidingsniveau's. Dit is overigens de enige studie, die een dergelijk demografisch patroon laat zien en men moet embij atntekenen dat hoe verder men teruggaat in de geschiedenis de betrouwbarheid van de diagnoses en de representativiteit van de registratie af kan nemen. Dergelijke gegevens zijn voor Nederland niet beschikbaar maar het onderzoek van van Ree (1981) en ons eigen onderzoek bij Rotterdamse gemeenteambtenaren naar de samenhang tussen opleidingsniveau en cardiovasculaire risico"s wijst er ook op dat het hartinfarct in Nederland nu het meest bij de lagere sociale strata voorkomt. Dit kan veroorzaakt worden door hun geringere toegang tot de informatie over schadelijke risicofactoren.

Op grond van mijn kllinische ervaringen geloof ik echter ook, dat het hartinfarct zich nu ook bij deze groep concentreert omdat zij nu als laatste toegang probeert te krijgen tot de welvaart van de geïndustrialiseerde samenleving door overwerk en dubbele banen. Ik ben tot die overtuiging gekomen tijdens de gesprekken die ik bij infarctpatiënten thuis gevoerd heb. Een van de beste researchinstrumenten in de medische psychologie is de koffie, die men thuis 
bij ecn patiant drinkt. Zou ik het ooit voor het zeggen krijgen in de speciahistenopleiding, dan zou ik ook een stage van een week bij de koffiebar van het zickenhus verplicht stellen. In ongedwongen situaties hoort en ziet men heel andere dingen dan in de spreekkamer of de kliniek. In de huiskamer van infarctpatienten ben ik wak getroffen door hel meubilair dat een zucht naar status uitdrukt en door de boeken in de kast, die gekocht zijn met de illusie dat zij toegang tot maatschappelijk aanzien zouden geven. Het is tragisch te zien hoe een infarctpatient gezeten in een zware leren fauteuil met grote oorkussens in de kamer van een kleine huurwoning wertelt over zijn overwerk of zijh dubbele baan, die hij aannam om een auto, een caravan of de opleiding van zin kinderen te kunnen betalen.

Vanwege deze verschwiving wan de hogere nar de lagere sociale strata geloof ik dat het hartinfarct als epidemisch probleem gaa uitdoven. Tot op zekere hoogte is dit een voorspelling over het verleden omdat de daling in cardiowasculaire mortaliteit in het westen al enige jaren aan de gang is tember kon $U$ in de krant lezen dat het aantal hartinfarcten in Nederland daalt". De algemene voorlichting over gezonde leefwijzen en de verbeterde cardiologische zorg lijken succes te hebben. Ik gelloof dat deze daling óok komt doordat wij in dric generaties langzaam geleerd hebben hoe te leven in een geindustrialiseerde wereld. Uit dit model is ook de hypothese af te leiden dat men nieuwe, leefwijzen-gebonden zikkten kan zien aankomen, door erop te letten of zich bij de hoogste sociale klassen stijgingen in het voorkomen van een ziekte voordoen. Zij zijn immers de eersten, die met een nieuwe levensstijl reageren op belangrijke sociale veranderingen. En als deze levensstijl het ontstaan van een ziekte bevordert dan moet een toename van die ziekte daar het eerst aangetroften worden. Bij de Wereld Gezondheids Organisatie is nu in studie of men een epidemiologisch bewakingssysteem, waarin ook gedragskenmerken zijn opgenomen, kan ontwikkelen. De afleiding van de demografische ontwikkeling is, het zij nogmaals gezegd, een speculatie die slechts door het onderzoek van Marmot en Rose gesteund wordt. Veel meer zekerheid bestaat erover dat het hartinfarct nu vooral bij de groepen met de laagste opleiding voorkomt ${ }^{\tau}$. En daarom is het wenselijk om de gezondheidsvoorlichting en opvoeding vooral op deze groep te richten.

\section{Vitalle uitputting en depressie}

Uit de beschouwing over de culturele voedingsbodem van het, ,coronary prone behavior" is een tweede afleiding mogelijk, die ons eindelijk op het terrein van de medische psychologie in strikte zin brengt. Wat het A-type en de moderne kunst gemeenschappelijk hebben, is de dynamisering van het levensgevool tesamen met het wegvallen van traditionele oriëntatiepunten, het gevoel opgetild te zijn binnen zich snel ontwikkelende processen. Van deze civilisatievorm heeft Marcuse (1969) een diepzinnige analyse gemaakt waarin hij, geinspireerd door Freud's "Das Unbehagen in der Kultur" stelt dat de toenemende druk van de civilisatie bij het individu het goeddeels onbewuste verlangen doet opkomen nar een autodestructief moment dat hem ontslaat van de Lasten, die de civilisatie hem oplegt. Deze cultuurfilosofische analyse bracht 
ons tot de afleiding dat het type A gedrag een uitputtingsslag met zichzelf is. Dit gedrag kan leiden tot een vitale uitputting, die gemakkelijk een depressieve inkleuring krijgt wanneer de persoon voelt dat hij er niet meer in slaagt zijn levensomstandigheden onder controle te houden. Als deze afleiding just is dan moet de infarctpatient op zijn weg naar het hartinfarct een periode van vitale uitputting en depressie doormaken. Iets anders geformuleerd luid deze affleiding: een gevoel van vitale uitputting en depressie behoort tot de prodromen van het hartinfaret. In deze vorm wordt de afleiding toetsbaar en vindt steun als de volgende hypothesen war blijken te zijn: 1. hartpatienten rapporteren gevoelens van vitale uitputting en depressie als kenmerkend voor de periode voor hun infarct. 2. zij die vitaal uitgeput en depressief zijn hebben meer kans op een dreigend hartinfarct. $3 \mathrm{zij}$ die vitaal uitgeput en depressief zijn hebben meer kans om binnen betrekkelijk korte tijd een infarct te krijgen dan zij die zich vitaal voelen. De eerste uitspraak hebben wij getoetst in een aantal retrospectieve studies. Daarbij bleek dat ongeveer twee-derde van de infarctpatienten een dergelijke periode kort voor hun infarct doormakte. Dat geeft enige steun aan de uitspraak maar een methodologisch probleem van deze en vele andere studies in de medische psychologie is dat wat een patient zegt zowel oorzaak als gevolg van zijn ziekte kan zijn. En daarom geldt ook voor de medische psychologie dat zij met epidemiologische methoden moet gaan werken om aan haar uitspraken echte bewijskracht te geven. Wij doen dat mu in een prospectief onderzoek bij ongeveer 4000 Rotterdamse gemeenteambtenaren. Deze deden allen mee aan een vrijwillig screeningsonderzoek. $Z \mathrm{ij}$ die op het moment van screening vitaal uitgeput en depressicf waren hadden met $95 \%$ zekerheid tenminste 4 keer zoveel kans op de diagnose ,dreigend infarct" (recente, verergerende of frequente angina pectoris en een ECG dat duidt op ischaemie) dan zij die vitaal waren (Appels en Mulder, 1982)... Dat steunt de tweede uitspraak.

Van de onderzochte mannen kregen er zes binnen drie maanden een hartinfarct. Vijf van hen waren vitaal uitgeput en depressief. De kans om binnen drie maanden een infarct te krijgen is met $95 \%$ zekerheid tenminste 5 keer zo groot voor hen die vitaal uitgeput en depressief zijn dan voor hen die zich fris en monter voelen. Dat geeft steun aan de derde uitspraak, maar hierbij moet opgemerkt worden dat deze gegevens nog iets voorlopigs hebben. De studie is nog niet afgesloten. Op het moment van onderzoek verschilden deze zes mannen significant van mannen, die gezond bleven op vragen als, mijn lichaam is als een batterij, die haar kracht of vermogen verliest", "ik heb het gevoel dat ik in het slop zit", ,ik heb de laatste tijd meer tijd nodig om aan de slag te komen". Het antwoord op deze vragen bleek niet mel de klassieke risicofactoren samen te hangen.

Deze resultaten laten zien dat het vruchtbaar kan zijn zich door cultuurfilosofen te laten inspireren. Maar omdat het medisch-psychologisch handwerk zich niet op het domein van de cultuurfilosofie afspeelt, levert het geen argumenten pro of contra het gelijk van de filosoof. Dat is ook niet de bedoeling. Tegelijkertijd hebben zij ons gebracht op het glibberig terrein van de epidemiologie van vermoeidheid, waar het zo moeilijk is uit te maken of een sluimerende ziekte de vermoeidheid veroorzaakt of dat lichamelijke processen door uitputting en depressie ontregeld raken of dat ziekte en depressie elkaar 
versterken. Tesamen met mijn collega's Falger en Lulofs werk ik aan de verdere bestudering van dit symdroom. Wij kunnen het nu redelijk meten en dat maakt de verdere studie van pathofysiologische processen mogelijk. Van daaruit wordt ook een bijdrage nogelijk aan de twee andere taken die de medische psychologie naast het onderzoek van de oorzaken van ziektes heeft, namelijk de studie van het gedrag van de zieke mens en het toepasbaar maken van deze kennis in therapie en revalidatie. In het cardiovasculaire domein betekent dat dat wij de depressie, die men in de cardiologische kliniek vaak ziet, niet zozeer beschouwen als een reactie op de ziekte maar als de voortzetting en uitdieping van een depressie die al voor het infarct bestond, en de loochening van de ziekte, de mededeling van de patiënt dat de cardioloog zich vergist heeft en dat er slechts sprake was van een lichte waarschuwing, als een poging greep op de levensomstandigheden te houden. Voor de cardiologische praktijk biedt de analyse van thet syndroom van vitale uitputting en depressie een perspectief op nieuwe en aanvullende methoden voor preventie en revalidatie. Wat de medische psychologie tor zo'n krachtige discipline maakt, is niet alleen dat zij de know-how heeft om het ontstaan van gedragsgebonden ziekten te bestuderen maar ook methoden om dit gedrag te veranderen. Het deelproject "gedragsveranderingen op leertheoretische basis" waarin een zevental collega's samenwerken, bewijst dit ruimschoots.

\section{Anorexila nervosa}

Mijn derde en laatste afleiding uit de kunsthistorische excursie betreft anorexia nervosa en het bange vermoeden dat deze ziekte epidemische vormen zal gaan aannemen ${ }^{8}$. Om deze afleiding toe te lichten gaan wij eerst nog terug naar de laatste zaal wan het imaginaire museum, naar de kunst van de laatste twee decennia, de kunst van de post-industriële samenleving?. De geschiedenis heeft hier haar filtrerende werking nog niet kunnen doen, zodat de bezoeker niet weet of hij het meest representatieve werk wel voor zich ziet. Wat hier opvalt en boeit, is een eigen keuze, die slecht te verantwoorden is ${ }^{10}$. Ik zie daar vooral creaties die aangeven dat de kunst een sociale dimensie gekregen heeft. De wijze waarop vanaf de zestiger jaren met ruimte en tijd wordt omgegaan is zo speels geworden, dat tijd en ruimte als boetseerwas geworden zijn. Christo, bijvoorbeeld, maakt transformaties van een heel landschap door er een killometerslang gordijn door te laten lopen of door een vallei met een gordijn af te sluiten. Deze transformaties zijn nooit een lang leven beschoren. Soms duren ze zells maar een nacht, zoals zijn afsluiting van een smalle straat met een antal olievaten, daar boze omwonenden de kunstenaar met emmers water verjoegen en woedend het kunstwerk afbraken om hun voordeur weer open te kunnen doen.

Om zijn "running fence" te kunnen maken moest Christo de medewerking krijgen van een aantal boeren door wier land zijn gordijn ging lopen en van het districtsbestuur. Dat bestuur zag weinig in Christo's plannen. Welke dwaas geeft immers meer dan een miljoen dollar uit om een gordijn twee weken in een paar weilanden op te kunnen hangen? Het districtsbestuur belegde een hoorzitting, die op film is vastgelegd. Op deze film ziet men een gezellige, 
goedgevulde boerin een pleidooi voor Christo houden met ongeveer de volgende woorden. "Meestal kook ik maar gewoon. Maar als ik af en toe eens lekker kook dan is dat kunst. Ik werk een paar dagen aan de voorbereiding en met zijn allen genieten we er een paar uur van". Op die uitspraak reageert Christo enthousiast want dat geeft nu precies zijn bedoeling weer. Deze discussie vormt een wezenlijk onderdeel van het kunstwerk, een van de redenen waarom het op film werd vastgelegd ${ }^{11}$.

De bedoeling van deze kunst is niet meer het maken van een werk dat de eeuwen kan trotseren. Het zijn kleurige, romantische eendagsvliegen. De toeschouwer is geen passieve observator meer. Het kunstwerk is pas af wanneer de toeschouwer meedoet, de ruimte en tijd, die ad hoc door de artiest geschapen zijn, binnentreedt en meedoet aan de happening. Zoals de barok het centraal perspectief opvulde door de monarch of de grote heilige stevig en vast in het verdwijnpunt te plaatsen, zo lijkt nu de open ruimte en tijd gevuld te worden door wisselende groepen mensen, die samen gedurende enige tijd iets ondernemen. Men ziet dat bij uitstek in het werk van de performance artiesten, maar bijvoorbeeld ook in de baletten van Pina Bausch, waarin danseressen de zaal in dansen of zich in een rij opstellen en om de beurt de bijnamen opnoemen, die zij op school ontwingen.

Met de hedendaagse kunst als getuige zeg ik dat tijd en ruimte een sociale dimensie gekregen hebben, waarin het type A gedrag minder functioneel wordt. Dat betekent dat zij kwetsbaar worden, die om welke reden dan ook gehandicapt zijn in het leggen van directe, spontane en informele relaties met anderen. Dat lijkt nu karakteristiek te zijn voor anorexia nervosa patiënten ${ }^{12.2}$. Anorexie is een ziekte die gekenmerkt wordt door een ziekelijke vermageringszucht. De keuze van anorexia nervosa (en bijvoorbeeld niet suicide of het coloncarcinoom) berust deels op een intuitie, die gesensibilizeerd is door de studies van mijn collega Weeda-Mannak, deels op de constatering van velen dat bij deze groep patiëntes een hoog plichtsbesef en een sociaal onvermogen samengaan en deels op aanwijzingen dat deze ziekte steeds meer voorkomt en vooral in de hogere sociale lagen $^{13}$. Deze laatste gegevens zijn overigens erg indirect en zwak. Over anorexia nervosa bestaat nog geen enkele goede epidemiologische studie.

Wanneer wij aan de ene kant zien dat tijd en ruimte een sociale dimensie krijgen en de civilisatie bijgevolg gekenmerkt wordt door een informaliseringsproces, zoals onder meer is uitgewerkt door de Utrechtse medisch psycholoog Cas Wouters (1977), en aan de andere kant steeds meer indirecte aanwijzigingen krijgen dat anorexia nervosa toeneemt, dan is te verwachten dat tussen deze twec processen een samenhang bestaat. Het aardige van de medische psychologie is dat het deze speculaties empirisch kan onderzoeken. Als het waar is wat ik vermoed, dan moeten anorexia nervosa patiëntes meer dan hun leeftijdgenoten moeite hebben met het informaliserende en socialiserende karakter van de huidige civilisatiefase.

Om deze bewering enigermate te staven hebben wij aan anorexia patiëntes en een vergelijkingsgroep van leeftijdgenoten een aantal vragen voorgelegd over hun waardering van moderne kunst als sociaal proces, over hun visie op kenmerkende elementen van het informaliseringsproces en over het vermogen directe, spontane relaties met leeftijdgenoten aan te gaan ${ }^{14}$. Vrijwel 
alle voorspelde verschillen werden inderdaad gevonden.

Ik lees $U$ een paar vragen voor. "In moderne toneelstukken betrekken de toneelspelers soms de zaal in de voorstelling. Een artistieke prestatie, zeggen $z \mathrm{j}$, lever je niet op een affstand maar maak je samen met het publiek". Wat vind je daarvan?" Anorexia patientes vinden dat een opdringerige gedachtengang, terwijl het hun generatiegenoten aanspreekt. De volgende twee vragen beogen rechtstreeks naar de waardering van het informalisatieproces te vragen. "In sommige gezinnen noemen de kinderen tegenwoordig hun ouders bij de voornaam en zeggen bijwoorbeeld Ans en Koen in plaats van mama en papa. Wat wind je daarvan?" "Jong getrouwde mensen zetten tegenwoordig valk alleen hun voornamen op de deur. Zou jij dat ook doen?" Anorexia patiẻntes vinden het significant vaker een onnatuurlijke zaak dat kinderen hun ouders bij de voornamen noemen en zijn er minder toe geneigd om alleen hun voornaam op de deur te zetten.

Uit vrijwel al hun antwoorden spreekt de angst van anorexia nervosa patiëntes on directe, informele en spontane relaties met leeftijdgenoten aan te gaan. $\mathrm{Zij}$ vinden het moeilijk om door leeftijdgenoten geaccepteerd te worden, vinden intieme relaties een inbreuk op de zelfstandigheid, nemen nooit het initiatief om sociale contacten te leggen, voelen zich onveilig in een clubje leeftijdgenoten, houden niet van informele kleding zoals een spijkerbroek, zeggen niet het type te zijn dat well ens lekker uit de band wil springen en geven zelden of nooit toe aan een sterke emotie omdat zij zich altijd goed willen kunnen beheersen. En dat zijn, naar hun zeggen, gevoelens en opvattingen, die al bestonden voordat zij onder behandeling kwamen.

Wanneer de bedding van het water verandert, wordt ook het gedrag wan vissen anders. De anorexia patiëntes lijken uit dat segment van de samenleving te komen, dat moeite heeft met de sociale dimensie die tijd en ruimte gekregen hebben. Op een bizarre wijze zet de anorexia patiënte daarbij het enig machtsmiddel in waarover vrouwen in de loop der eeuwen beschikt hebben: hun lichaam. Anorexia patiëntes zeggen in ons onderzoek ook significant vaker dan hun generatiegenoten dat zij een grote teleurstelling hebben meegemaakt in het contact met iemand anders. En omdat de lichamelijke verschijningsvorm in het vestigen van sociale contacten bij vrouwen toch vaak nog een grotere betekenis heeft dan bij mannen, geloof ik dat anorexia nervosa vooral yoorkomt bij vrouwen, Het equivalent kan ook bij jongens anorectisch gedrag zijn, maar het zou belangrijk zijn om te onderzoeken of er ook andere equivalenten bij hen gevonden worden. Wanneer deze gevonden zouden worden, zou men wellicht de makers van een nieuwe epidemie hebben opgespoord. Voor het zover is zal nog veel werk verzet moeten worden. Het zojuist genoemde onderzoek is niet meer dan een eerste peiling, een seismografisch onderzoek, dat het waarschijnlijk maakt dat zich onder de oppervlakte zaken bevinden, die de moeite van verdere exploratie waard zijn. Weerom geldt overigens, dat informatie verzameld op het ene (psychologisch) niveau geen bewijs kan leveren voor de geldigheid van een uitspraak, die men op een ander (epidemiologisch) niveau doet. Een cultuuranalytische invalshoek kan bijdragen aan thet formuleren wan nieuwe hypothesen en aan het ontwikkelen van een nieuwe researchstrategie naar de oorzaken van de (relatieve) opkomst en neergang van leefwijze-gebonden ziektes. Wanneer ik in dit 
verband mijn vermoeden uitspreek dat de incidentie van anorexia nervosa toeneemt, dan betekent dat niet dat ik geloof dat er straks evenveell anorexia patiëntes zullen zijn als er nu hartpatiënten zijn. Ik geloof eerder dat wij nu op de dalende helling van de berg van hart- en vaatziekten zijn en op de stijgende helling van een heuvel van anorexia nervosa. De redenen hierwoor liggen voor de hand. Bij anorexia nervosa spelen leefwijzen en karakter (waarschijnlijk) de grootste rol in het ontstaan van de ziekte, terwijl zij bij hart- en vaatziekten een onderdeel zijn van een complex multifactorièel proces, waarin leeftijd (dat hier staat voor veroudering en slijtage) niet de geringste determinant is. Voor de therapie van anorexia nervosa-patiëntes betekent deze cultuurpsychologische analyse, dat zij zich ook moet richten op het herstel van het vertrouwen van het vertrouwen dat men anderen schenkt wanneer men diens ruimte binnentreedt. Deze formulering, vertrouwen van het vertrouwen dat men anderen schenkt" klinkt cryptisch maar laat zich eenvoudig uitleggen. Het menselijke van menselijke emoties is dat wij er weet van hebben. Al onze emoties zijn dubbelgelaagd. De angstige is angstig voor zijn angst, de depressieve depressief om zijn depressie, de anorexia patiënte vertrouwt haar vertrouwen niet dat zij anderen zou willen schenken.

\section{Samenvattend: het begrip ,tijd" in kwnst en gedrag}

Mijnheer de rector, dames en heren. Ik heb het gevoel dat velen van $U$ mij nu met vragen zouden willen bestormen. Daar is ook alle reden voor want ik heb meer gesuggereerd dan bewezen. Ik heb het $\mathrm{U}$ ook niet al te gemakkelijk gemaakt. Een korte samenvatting is daarom wel gewenst. Ziektes die ook door leefwijzen veroorzaakt worden, weerspiegelen ook een cultuur. Tot de cultuur behoren veel dingen. Daaruit heb ik één ding genomen, namelijk de kunst. De vraag van deze openbare les was: kan een analyse van de moderne kunst ons iets meer laten begrijpen van het gedrag dat het ontstaan van sommige ziektes bevordert? Daartoe ben ik ingegaan op het begrip ,tijd"' in kunst en gedrag.

In het begin van deze eeuw ziet men aan veranderingen in de kunst dat de mensen en dingen niet meer in de tijd zijn maar dat de tijd in de dingen en de mensen komt. De futuristische schilders verheerlijken in hun manifesten vrijwel letterlijk het gedrag dat wij nu het A-type noemen. Dat tekent de leefwijzen van de industriële samenleving. En in mijn ogen is dat de voedingsbodem voor de explosie van hart- en vaatziekten.

In de zestiger jaren, wanneer het post-industriële tijdperk begint, krijgt de kunst een sociale dimensie. Dat betekent dat de cultuur steeds meer een beroep gaat doen op het vermogen van mensen om informele, spontane relaties met anderen aan te gaan. Omdat zij die in dat vermogen gehandicapped zijn kwetsbaar zijn woor het krijgen van anorexia nervosa geloof ik dat we in de komende decennia een toename van AN zullen krijgen. Een cultuurpsychologische analyse is als het ware een van de filters die we voor onze onderzoekslens kunnen zetten. $U$ weet, verschillendle filters maken verschillende dingen zichtbaar. Dat zo'n analyse nuttig is, heb ik geillustreerd aan de hand van drie afleidingen betreffende de demografische ontwikkeling van het hartinfarct, 

patientes.

Uit deze analyse mag U niet afleiden, dat ik zou geloven dat hart- en vaatziektes volledig zouden verdwijnen en de anorexia nervosa de eerste doodsoorzaak zou worden. $\mathrm{l}$ heb alleen getracht iets inzichtelijker te maken waarom wij nu een daling van coronaire hartziekten en een stijging van anorexia nervosa meemaken.

Door dit te doen heb ik $U$ het feestelijke van de medische psychologie willen laten zien, dat ligt in het intellectuele genot van het zoeken naar de samenhang tussen ogenschijnlijk heel verschillende vormen van gedrag. Ik heb $\mathrm{U}$ willen laten zien, dat wil men het groeien van een plant bestuderen men ook in ogenschouw moet nemen in wat voor omgeving deze staat. Het taaie van de medische psychologie, het zweet dat ons vak deelt met elke serieuze wetenschap, het selecteren van proefpersonen, het oplossen van meetproblemen, het toetsen van alternatieve verklaringen (en voor elk door mij beschreven fenomeen zijn meerdere verklaringen mogelijk), al die dingen die $90 \%$ van onze onderzoekstijd vullen, heb ik U bespaard.

Door mijn keuze van cultuur en ziekte als thema heb $\mathrm{ik} U$ weinig kunnen vertellen over de ontwikkelingen, die vandaag plaats vinden in de zogenaamde "behavioral medicine", ontwikkelingen die een antwoord geven op de vraag waarmee studenten en medici ons even permanent als terecht belagen: "wat kan ik met de psychologie doen?" Door deze keus heb ik mijzelf ook de kans ontnomen iets te zeggen over het onderwijs. Het presenteren van gedachten die te denken geven, is overigens het eerste wat men van een docent mag verwachten. Dat hoop ik gedaan te hebben en te blijven doen.

Mijnheer de rector, dames en heren. Het is een voorrecht de medische psychologie te mogen beoefenen en $U$ daarover wat te mogen vertellen. Daarom wil ik mijn dank uitdrukken aan allen, die ex officio mijn benoeming mogelijk maakten en aan drie personen in het bijzonder.

Mijn vader wil ik hier kort gedenken. Ik herinner mij nog heel goed dat hij mij in 1949 vertelde dat er een onderzoek gedaan was naar het IQ van nederlandse professoren. Dat bleek erg tegen te vallen. Maar wat zij meer dan anderen hadden was een grote belangstelling en een grote ijver. Dat onderzoek had hij, denk ik, uit cle Tilburgse krant, een blad dat niet direct vergelijkbaar is met de scientific american. Maar er zit misschien wel iets in. Een vehemente bellangstelling is de basis van de wetenschapsbeoefening. En dat heeft hij uitzonderlijk gestimuleerd.

Mijn vrouw, Yvonne Estourgie, zou ik willen noemen, maar wat ik haar te zeggen heb behoort tot het privé domein van ons vijven, waarin wij ons tot nu toe mochten koesteren als onder een italiaanse hemel.

Joost Bremer wil ik noemen, die de afdeling gesticht heeft en deze als een benedictijnse abt beheert. In deze communiteit ben ik nu prior, die goed weet wat Benedictus in zijn kloosterregel over deze functie geschreven heeft. Dat zijn vooral waarschuwingen aan abt en communiteit. Maar het zal nu wel duidelijk zijn dat ik een tegenstander ben van aparte priorijen, omdat de medische psychologie juist haar kracht ontleent aan de combinatie van onderzoek naar oorzaken van ziekten en het van daaruit ontwikkelen van toepassingen in de gezondheidszorg. 
Dames en heren, beste vrienden. Het is goed dat een universiteit momenten kent waarop op feestelijke wijze een vakgebied geherintroduceerd wordt. Het is ook goed dat onze wereld informeler wordt. En daarom stel ik $U$ voor dat $U$ de lange quetu van de receptie ontloopt om meteen naar het trefcentrum te gaan, waar wij elkaar wel zullen vinden.

Ik heb gezegd.

\section{Noten}

1. De intieme verwantschap tussen tijd en waameming is in de wijsbegeerte vooral door Augustinus belicht. ,De essentie van Augustinus' redenering was dat tijd bestaat uit verleden, heden en toekonst, dat wil zeggen uit herinnering, waarneming en verwachting. Aangezien zich iets herinneren eigenlijk een waarneming van het herinnerde is en aangezien verwachting eigenlijk een warneming van het verwachte is, is dus de essentie van de tijd de mogelijkheid tot waarneming" (Van Arkel, 1974).

2. De schilder (observator) herstelt de eenheid van conceptie die verloren gaat door de noodzaak steeds wisselende gezichtspunten in te nemen. Hetzelfde doet de denker of de oordelende mens in de filosofie van Kant. Kahnweiler, een kwnsthandelaar die als een van de eersten kubistische werken ten toon stelde, heeft reeds in 1920 gewezen op de overeenkomst tussen de filosofie van Kant en de werkwijze van de kubisten (Gehlen, 1960).

In de psychologie wordt aan Kant weinig aandacht besteed. Toch zou het de moeite waard zijn om uit te werken in hoeverre men een aantal denkvormen van mensen zo beter zou kunnen begrijpen. Dat geldt met name voor de ethiek van Kant. Zoals tijd een apriori categorie van het menselijk kennen is, zo is er in zijn filosofie een zedelijke wet, die cen absolute verplichtingswaarde heeft. Kant noemt dit de categorische imperatief: „Handle so, dass die Maxime deines Willens jederzeits zugleich als Prinzip einer allgemeinen Gesetzgebung gelten könne", een principe dat klinkt als een gelaiciseerde formulering van de westerse nadruk op het eigen geweten en van de protestantse ethiek in het bijzonder.

Het denken en oordelen in categorische imperatieven ziet men bij mensen terug in een uitgesproken verantwoordelijkheidsgevoel, het opleggen van hoge normen aan zichzelf en anderen, ook in situaties waar dit niet direct nodlig is. Tot op grote hoogte weerspiegelt het gedrag wan de hartinfarctpatiènt allerlei categorische, onbediscussieerbare categorieën. Zijn hoog ontwikkeld geweten, verantwoordelijkheidsgevoel en rechtvaardigheidszin hebben hem vaak voortgedrewen en niet zelden zal men hem horen vertellen dat een conflict met of om iemand die zich niet verantwoordelijk gedroeg de oorzaak van zijn infarct was. Als zodanig zou men het hartinfarct vaak tot de pathologie van het super-ego kunnen rekenen.

De rationeel-emotieve therapie van Ellis richt zich juist op die psychische problemen die ontstaan wanneer de afstand tussen een ideaal ,sollen" en de alledaagse feiten te groot is geworden. Ellis' therapie bestaat uit frontale anvallen op de categorische imperatieven, die mensen onnodig hanteren (Ellis, 1974). Hij is ook de enige psycholoog bij wie ik ooit een expliciete verwijzing naar Kant gelezen heb. In de revalidatie van infarct- 
patienten is deze therapie nooit expliciet toegepast, terwijl dit een goede keus zou kunnen zijn.

3. In nazi-duitsland zal dit later ,entartete Kunst" genoemd worden. Fascisten zijn niet zo op relativiteit gesteld. Het nazi-dom stelde de grote leider of diens absolutistisch symbool in het verdwijnpunt van het centraal perspectief. Het fascisme is een vorm van decadente barok en leek ook bij voorkeur te ontstaan in gebieden die vroeger een exuberante barok gekend hadden.

4. In dit opstel wordt alleen ingegaan op het jachtige, dynamische karakter van het moderne leven en de weerspiegeling daarvan in het type A gedrag. In dat laatste gedrag is de factor agressiviteit-wijandigheid tenminste even belangrijk, zo niet belangrijker. De oorsprong van deze agressiviteit is zowel op psychologisch als op sociocultureel niveau nog nauwelijks onderzocht en begrepen. Uit therapie programma's blijkt dat hartpatienten weinig moeite hebben om hun jachtigheid en haast te onderkennen en daar wat aan te doen, maar zichzelf niet begrijpen bij de vraag waarom zij zo vijandig-agressief zijn (Thoresen, Telch en Eagleston, 1981).

5. Zou men op de wereldkaart intekenen in welke landen hart- en vaatziekten het meest voorkomen dan zou men zien dat deze ziekte a.h.w. als een gordel om de aarde ligt, een gordel die grotendeels samenvalt met de geindustrialiseerde landen. Het lijkt erop dat het aantal infarcten het meest stijgt in de landen die zich betrekkelijk recent zijn gaan industrialiseren.

Onderstaande tabel laat van een aantal landen de daling, c.q. stijging in de sterfte ten gevolge van ischaemische hartziekten zien (WHO, 1982).

Jaarlijkse verandering $(\%)$ van de mortaliteit ten gevolge van ischaemische hartiekten in 26 landen van 1968 tot 1977.

mannen

$\begin{array}{lrr}\text { U.S.A. } & -3.0 & -3.6 \\ \text { Japan } & -2.6 & -4.7 \\ \text { Australie } & -2.1 & -1.0 \\ \text { Finland } & -1.8 & -1.6 \\ \text { Belgie } & -1.7 & -1.1 \\ \text { Canada } & -1.6 & -0.9 \\ \text { Nieuw Zeeland } & -1.2 & -1.6 \\ \text { Noorwegen } & -1.1 & -0.3 \\ \text { Nederland } & -0.9 & +0.8 \\ \text { Italie } & -0.1 & -2.0 \\ \text { Schotland } & +0.1 & +0.5 \\ \text { Zwitserland } & +0.2 & -3.5 \\ \text { Engeland } & +0.3 & +1.1 \\ \text { West-Duitsland } & +0.4 & +0.5 \\ \text { Oostenrijk } & +0.6 & +0.3 \\ \text { Tsjecho-Slowakije } & +0.6 & 0.0 \\ \text { Frankrijk } & +1.1 & -1.4\end{array}$


Noord-Ierland

Denemarken

Zweden

Hongarije

Ierland

Roemenie

Bulgarije

Joegoslavie

Polen
$+1.3$

$+1.7$

$+2.0$

$+2.6$

$+2.6$

$+4.3$

$+5.6$

$+0.6$

$+6.4$
$-0.2$

$+0.7$

$+1.8$

$+2.0$

$-0.4$

$+3.8$

$+2.5$

$+4.1$

$+5.2$

6. Deze krantenberichten berustten op een artikel van D. Hoogendoorn (1982) in het Nederlandse Tijdschrift voor Geneeskunde. Dit artikel laat zien dat de top van de cardiovasculaire epidemie in 1972 lag. Indien in 1980 per leeftijdsgroep dezelfde mortaliteitscijfers zouden hebben gegolden alls in 1972 dan zouden in 19805375 personen méér aan deze aandoeningen zijn overleden dan in werkelijkheid het geval is geweest. Opvallend is dat de sterfte in Groningen en Limburg $40 \%$ hoger is dan in Zeeland - Utrecht - Noord Holland. Bij deze gegevens wil ik twee aantekeningen maken.

1. Het betreft hier sterftegegevens en geen ziektegegevens. Het kan zijn dat niet het aantal infarcten gedlaald is maar alleen de sterfte ten gevolge van het hartinfarct. Waarschijnlijk geldt de daling echter zowel voor morbiditeit als mortaliteit.

2. Het lijkt de generatie te zijn die na de wereldoorlog Nederland heeft opgebouwd, die hiervoor de tol betaald heeft. De cijfers van Groningen en Limburg zouden dan (misschien) verklaard kunnen worden door hun afwijkende industrialisatiegeschiedenis in de afgelopen 35 jaar.

7. Bij mensen uit de laagste opleidingsniveau's komen niet alleen meer infarcten voor, zij overlijden ook vaker ten gevolge van het infarct. Weinblatt (1978) volgde 1739 mensen, die hun eerste infarct overleefd hadden om na te gaan welke factoren de kans op een plotselinge dood verhoogden. Daarbij bleek dat zij die alleen de lagere school bezocht hadden en die complexe ritmestoornissen hadden meer dan driemaal zoveel risico hadden om binnen drie jaar plotseling te sterven dan zij die dezelfde ritmestoornissen hadden maar een hogere opleiding genoten hadden. In een commentaar op deze studie geeft Jenkins (1978) de volgende uitleg van de resultaten. Mensen met een lage opleiding zijn inadequaat voorbereid op de complexiteiten van het moderne stadsleven. Zij zijn minder in staat de dagelijkse problemen op te lossen en de feedback die zij ontvangen te gebruiken om nieuwe moeilijkheden te voorkomen. Dit dwingt hen in ondergeschikte posities, waar de gezins- en werkverbanden fragieler zijn en do sociale steun geringer is. Deze tekorten leiden tot een grotere kans op frequente, hevige en langdurige alarmsituaties, die middels het neurohormonale systeem kunnen leiden tot toegenomen atherosclerose, degeneratieve veranderingen in het myocard en ritmestoornissen.

8. De intuitie dat verschuivingen in het culturele waardenpatroon het ontstaan van anorexia nervosa bevorderen en dat het aantal gevallen daardoor stijgt is al meer dan tien jaar geleden verwoord door Ch. Lafeber. 
Evenals Selvini-Palazzoli (1975) en Houben (1981) geeft zij daarbij een grote betekenis aan het gezin als de plaats waar culturele verschuivingen tot onduidelijkheden en conflicten in de onderlinge rollen kunnen leiden, die het ontstan van AN zouden bevorderen. Lafeber (1971) zegt daarover: „De algemene indruk is dat de anorexia patiênte vooral uit dat gezin voorkomt, dat te midden van een snel veranderende culturele wereld de traditionele vorm sterk neigt te handhaven".

Tijdens zijn inleiding bij een symposium over anorexia nervosa dat in 1981 te Leuven gehouden werd formuleerde Pierloot (1981) de algemene indruk over de stiggende incidentie vam $\mathrm{AN}$ als volgt: "Voortdurend rijst de vraag of anorexia nervosa thans meer voorkomt dan vroeger. Waarschijnlijk werden een aantal gevallen, vooral van lichtere aard, vroeger miskend. Mogelijk kwamen ze ook in andere ziektecategorieën terecht. ... Onafgezien daaryan kan men zich toch niet van de indruk ontdoen dat, althans in onze westerse maatschappij, de aandoening in frequentie toeneemt. Verbanden met maatschappij- en cultuurkarakteristieken kunnen hier een voorwerp van diverse speculatieve beschouwingen uitmaken".

9. Economen onderscheiden vijf fasen in de economische ontwikkeling van een land, lopend van de traditionele samenleving tot het tijdperk van de massaconsumpties (Rostow, 1969). Wanneer men deze indeling volgt lijkt het dat de epidemie van hart- en vaatziekten stijgt wanneer de economie tot volle wasdom komt en gaat dalen in de vijfde fase: het tijdperk van de massaconsumptie, de postindustriële samenleving. In deze fase verandert woor velen de structuur en de aard van de arbeid. Er werken nu meer mensen in de dienstverlening dan in de industrie. Er zijn nu meer "witte-boord" werkers en geschoolde arbeiders, die er bewust naar streven de vruchten van de tot volle wasdom gekomen economie in de vorm van gebruiksgoederen te genieten. De verzorgingsstaat ontstaat. De eisen die de cultuur aan mensen stelt veranderen. Het oude prestatie ethos (hoogst functioneel in eerdere fasen) komt in een kritisch licht te staan. De taken van het gezin worden anders en daarmee de structuur van het huwelijk. Personeelsadvertenties vragen niet meer om een dynamische, energieke man maar stellen nu goede contactuele eigenschappen voorop. De welvaartsstaat heeft haar eigen ethos.

Anno 1982 worden wij echter geconfronteerd met een crisis van de verzorgingsstaat en een toenemende werkloosheid. Terecht eist dit onze aandacht op want voor velen zijn de gevolgen afschuwelijk. Tot nu toe lijkt het op een crisis binnen de verzorgingsstaat en zijn de psychologische effecten van deze crisis wellicht feller maar toch minder diepgaand en ingrijpend dan die van het bestaan van het tijdperk der massaconsumptie en de verzorgingsstaat zelf. Mijn pen aarzelt wel wanneer ik dit schrijf, want niemand kent nog de afloop en de uitkomst.

10. Omdat veranderingen in de perceptuele organisatie van ruimte en tijd naar ik meen de belangrijkste veranderingen zijn die zich in het menselijk gedrag kunnen voltrekken ken ik aan veranderingen in de vorm meer gewicht toe dan aan veranderingen in de wijze van emotionele uitdrukking. Daarom heb ik mijn keuze voor wat ik het meest kenmerkend acht in de moderne en hedendaagse kunst niet laten vallen op het (abstract) expres- 
sionisme.

11. De sociale dimensie van Christo's werk wordt door Ellen Joosten (1978) als volgt beschreven: „Elke realisatie wordt veroverd in een jarenlang gevecht en een jarenlange discussie; en elke realisatie ontstaat midden in het leven van alledag en wordt afhankelijk gemaakt van de totale medewerking van allen die erbij betrokken zijn: werkers en beschouwers. Het feit dat er zoveel mensen bij de presentatie en de uitwoering betrokken worden, en de constatering dat deze mensen vrijwel zonder uitzondering zo hevig bij de hele onderneming betrokken raken, dat hun houding tegenover dit zogenaamde a-functionele kunst-gebeuren alle mogelijke gradaties van woede en enthousiasme vertoont, is karakteristiek en wezenlijk. Christo zoekt deze confrontatie.

De sociale dimensie van het werk van $P$. Bausch kwam opvallend naar voren in de balletten die uitgevoerd werden tijdens het Holland Festival 1981. Grote delen daarvan leken rechtstreeks overgenomen te zijn uit de groepstherapie.

12. Hilde Bruch (1977) noemt als het centrale probleem van de AN: „Why are the youngsters so unprepared to meet the challenge of adolescence namely the need to grow beyond the immediate family and to engage in relationships with members of their own age group?".

13. Het feit dat vrijwel alle psychologische publicaties over anorexia nervosa opmerken dat deze patiëntes zo opvallen door hun hoge plichtsbesef is voor mij een van de redlenen om AN een plaats te geven bij de cultuurgebonden ziekten. Dit argument behoeft een toelichting. Voor de bestudering van sociale processen en van veranderingen die over kortere of langere tijd uitstrekken zou de psychologie kunnen profiteren van een indeling die de franse historicus Braudel heeft gemaakt (Braudel, 1979; Peeters, 1978). Deze onderscheidt de tijd van de korte duur, de middellange duur of conjunctuur en de lange duur. De tijd van de korte duur is de tijd van het evenement, van de journalistiek, van de voorvallen in het dagelijks leven. De tijd van de conjunctuur of middellange duur is in de tijd van prijscurves, demografische progressies, ontwikkelingen in productie en verkeer, die een tot twee generaties omvat. Het is die tijd warin een gedragsgebonden epidemie kan opkomen en dalen. De tijd van de lange duur is de tijd van structuren, van mentale kaders, van tamelijk vaste elementen zoals de geografische ligging van een stad. Om geschiedenis (en gedrag, zegt de psycholoog) transparant te maken zou aangegeven moeten worden wat daarin evenementieel, conjunctureel of structureel is. In het domein van de medische psychologie behoren zaken als stressful life events, het slecht nieuws gesprek, de beleving van een ziekenhuisopname tot het gebied der evenementen. Veranderingen in ziektebeelden, zoals bijvoorbeeld de hysterie, verschuivingen in attitudes met betrekking tot abortus en euthanasie of het ontstaan van karaktertrekken als het Atype tot het gebied van de conjunctuur. Tot het gebied van de lange duur behoren bijvoorbeeld studies als. Freud's Unbehagen in der Kultur. Tot dit gebied behoort mijns inziens ook de studie van het persoonlijk verantwoordelijkheidsgevoel en het individuele geweten in het westers denken en voelen. Het is een westers mentaal kader bij uitstek. De grieks- 
christelijke erfenis heeft ons geleerd te denken in absolute termen van goed en kwaad, van waar en onwaar. Wij kennen, in tegenstelling tot bijvoorbeeld Japan, een persoonlijke God, die absolute morele geboden uitvaardigt, en kategorische imperatieven over wat goed gedrag is. De nadruk op de individuele verantwoordelijkheid en het persoonlijk geweten, in hoeweel harde of zachte varianten dit in de loop van de eeuwen ook verwoord is, en hoe verschillend ook ingevuld voor wat de instantie betreft tegenover wie men verantwoording schuldig is (God; de gemeenschap, een abstract ideaal wan menselijkheid) behoort tot de constanten van de europese geschiedenis en maakt Europa tot de moeder der revoluties.

Wil men spreken van een westerse cultuurziekte dan zal daarin steeds sprake moeten zijn van een conflict tussen een hoog normbesef en de al dan niet vermeende onmogelijkheid daarnaar te leven. De aard van de ziekte kan wisselen met de dominante waardenpatronen van een bepaalde conjunctuur, maar het hoge plichtsbesef of het scherp gevormde superego is gemeenschappelijk.

Het ligt daarom onder meer voor de hand om in de studie van de persoonlijkheid en het gezin van de anorexia patiënte na te gaan wat men daar terug vindt van dat andere lijden aan het super-ego dat men type A gedrag genoend heeft.

14. Voor dit onderzoek was een nieuwe vragenlijst ontworpen. Deze bestond uit 26 vragen van het type "Het is voor een meisje moeilijk om door leeftijdsgenoten geaccepteerd te worden" Ja!! -ja!-ja-nee-nee!-nee!! en uit dertien multiple-choice vragen. Om er zeker van te zijn dat in de controlegroep geen anorexia nervosa patiëntes zouden zijn was nog de vraag toegevoegd: Hebt $U$ in het laatste jaar contact gehad met een arts wegens gewichtsverlies of menstruatiestoornissen.

De vragenlijst werd in sommige gevallen door een therapeut aan de patiënte gegeven en in andere gevallen door een kennis of familielid. (Wij willen hier onze dank uitspreken aan dr. E. Houben, S. Sporken, N. Bär en $M$. van den Hout voor hun medewerking). Omdat uit vooronderzoek gebleken was dat het verzamelen van de data op moeilijkheden zou kunnen stuiten wegens redenen van privacy werden geen verdere gegevens over leeftijd en klinische karakteristieken verzameld. Wel werd een leeftijd van dertig jaar als bovengrens aangehouden. In de instructie werden de patiëntes nadrukkelijk gevraagd weer te geven hoe zij voelden en oordeelden voordat zij onder behandeling kwamen. Of deze instructie echt werkte kon niet worden nagegaan. In totaal werden negentien vragenlijsten ontvangen.

Als controlegroep fungeerden leerlingen van een sociale academie, van een opleiding tot verpleegkundige en van de hoogste klas van een middelbare school. In totaal werden 70 vragenlijsten uit de controlegroep ontvangen. (Wij willen onze dank uitspreken aan de heren $W$. Paulissen en K. Appels en aan drs. E. Bots-Estourgie voor hun medewerking). Achtentwintig van de negenendertig vragen bleken tussen beide groepen te discrimineren ( $\mathrm{x}^{2}$-toets). Naast de in de tekst geciteerde items bleken ook de volgende uitspraken tussen beide groepen te discrimineren. Deze zijn hier 
weergegeven in de wijze waarop AN patièntes zichzelf beschrijven: „Het is moeilijk te achterhalen hoe leeftijdsgenoten je beoordelen. In sociale contacten moet je je gevoelens vaak onderdrukken. Zelfvertrouwen leer je alleen door jezelf helemaal onafhankelijk van anderen op te stellen. Ik kan erg verlangen naar iemand die mij persoonlijk leiding geeft. Ik vind het vaak moeilijk te kiezen wat voor kleding ik moet dragen. Ik voel mij wel eens jaloers op meisjes, die goed voor hun mening durven uitkomen. Ik voel mij hulpeloos. Ik heb in mijn contacten met anderen dingen meegemaakt, waardoor ik mij soms knap waardeloos kan vinden. Ik vraag mij af of anderen mij accepteren. In de keuze van mijn kleding laat ik mij sterk leiden door de groep waar ik naar toe ga. Een intieme, persoonlijke relatie maakt je te gauw afhankelijk van die ander. Iemand in vertrouwen nemen vind ik moeilijk. Als ik een kledingstuk kies let ik er vooral op hoe anderen mij daarin zien. In een groep leeftijdsgenoten gedraag ik mij heel anders dan thuis. Over persoonlijk-lichamelijke zaken, zoals menstruatie, spreek ik nooit met andere meisjes.

De antwoorden op verschillende van deze vragen kunnen, ondanks de instructie, beïnvloed zijn door de ziekte zelf. Een tweede critisch punt betreft de specificiteit van deze vragen. Vanwege het feit dat een aantal meer algemene klaag-items (,Ilk denk dat leeftijdsgenoten op mij neerzien". „Belangrijke beslissingen nemen vind ik moeilijk") niet tussen patiëntes en controles discrimineerden geloof ik dat de vragen hun onderscheidend vermogen niet ontlenen aan het feit dat een labiele, neurotische groep vergeleken wordt met een gezonde groep. Uiteraard kan de vraag niet beantwoord worden hoe andere patiëntengroepen deze vragen zouden beantwoorden. Dat zal verder onderzoek moeten leren. Het medisch psychologisch onderzoek doet er echier goed aan de betekenis van de specifiteitswraag wat te relativeren. Zoals roken een determinant is van hartziekten en longkwalen, zo kunnen ook psychologische trekken de kans op het krijgen van verschillende ziekten verhogen. Een bepaalde factor kan voor de theorie en de gezondheidszorg belangrijk zijn zonder dat zij exclusief aan één ziekte gerelateerd is.

Bij het ter perse gaan van dit opstel verscheen een artikel dat een invulling geeft aan mijn vermoeden dat er een mannelijk equivalent van anorexia nervow moet zijn. Dwangmatige joggers (,obligatory runners"), een groep die in omwang steeds toeneemt, bleken veel punten van overeenkonst te hebben met $\mathrm{A} N$-patiëntes. Yates, A. Leehey, $\mathbb{K}$, and Shisslak, C.: Running-an-analogue of anorexia? New Engl. J. Med, 251-255, 1983.

\section{Literatuiur}

Apolonio, U., Futurist Manifestors. Thames and Hudson, London, 1973.

Appels, A. en Mulder, P.: Psychische prodromen van het hartimfarct. T. Soc. Geneesk., $60,821,1982$

Arkel, D. van: Over de onlwikkeling en gevolgen van het westers tijdsbemustzijn. De Gids, 9/10,609-619, 1974.

Berger, J.: Het moment wan kubisme. Sun, Nijmegen, 1972.

Braudel, F.: Geschiedschrijving. Ambo, Baarn, 1979.

Bruch, H.: Psychologicall antecedents of anorexia nerwosa. In: R. A. Vigerskey (ed.). Anorexia Nervosa. Raven Press, New York, 1977.

Ellis, A.: Humanistic Psychotherapy. McGraw Hill, New York, 1974.

Fortmann, H.: Wat is er met de mens gebeurd? Spectrum, Utrecht, 1961

Fry, E.: Cubism. 'Thames and Hudson, London, 1966. 
Gehlen, A.: Zeir-Bilder. Athenaeum Verlag, Frankfurt a. M., 1960.

Hauser, A.: Sociale geschiedenis van de kunst. Sun, Nijmegen, 1975.

Hoogendoom, D.: Dalende landelijke sterfte aan acuut hartinfarct en aan andere ischemische hartziekten. Ned. Tijdschr. Geneesk, 1691-1696, 1982.

Houben, M. E., Onderzoek naar enkele relatie-karakteristieken in gezinnen met een anorexia nervosa-patiënte. Tijdschr. Psychlatrie, 23, 87-90, 1981.

Jenkins, C. D.: Low education; a risk factor for death. New Engl. J. of Med., 299, 95-97, 1978.

Joosten, E.: Christo. Rijksnuseum Kröller-Müller, Otterlo, 1978.

Lafeber, Ch.: Anorexia Nervosa. Stafleu, Leiden, 1971.

Marcuse, H.: Eros and Civilization. Sphere Books, London, 1969.

Marmot, M. G., Adelstein, A. M.; Robinson, N. en Rose, G.: Social class distribution of heart disease. Brit. Med.J., 2, 1109-1112, 1978.

Mar\%, K.: Das Kapital. Dietz, Berlin, 1975.

Peeters, H.: Hislorische Gedragswetenschap. Boom, Meppel, 1978.

Pierloot, R.: Inleiding, Tijdschr. Psychiatrie, 23, 3-4, 1981.

Pieterson, M. (red.): Het technisch labyrinth. Boom, Meppel, 1981.

$\mathrm{Ree}_{3}$ J. W. van: Het Nijmeegs Interventie project. Academisch proefschrift, Nijmegen, 1981.

Rosenman, R. H. en Chesney, M: The relationship of type A behavior pattern to coronary heart disease. Act. Nerv. Sup., 22, 1-44, 1980.

Rosenman, R. H., Jenkins, C. D., Brand, R. J., Friedman, M., Straus, R. en Wurm, M: Coronary heart disease in the Western Collaborative Group Study: final followup experience of 8 years. $J A M A, 233,872-877,1975$.

Rostow, W.: De vijf Jasen van economische groei. Aula, Utrecht, 1969.

Schorske, C.: Fin-de-sicle Vienna. Politics and Culture. A. Knopf, New York, 1980.

Selvini-Palazzoli, M.: Self starvation. From the intrapsychic to the transpersonal approach 10 anorexia nervosa, Chauces, London, 1974.

Tisdall, C. en Bozzola, A.: Futurism. Thames and Hudson, London, 1977.

Thoresen, C., Telch, M. en Eagelston, J.: Approaches to altering the type A behavior pattern. Psychosomatics, 22, 472-482, 1981.

Weinblatt, E. e.a.: Relation of education to sudden death after myocardial infarction. New England J. of Med., 299, 60-65, 1978.

WHO, World Health Statistics, vol. 35, 1982.

Wouters, C.: Informalisation and the civilising process. In: Gleichman, P., Goudsblom, J. en Korte, H.: Human Figurations, Essays for Norbert Elias. Amsterdams Sociologisch Tijdschrift, 1977. 